\title{
EVALUATING THE POLITICAL RELEVANCE OF INTERNATIONAL RELATIONS THEORY
}

\section{RAMESHWARI BHOI}

Assistant Professor, Department of Political Science and Public Administration, MA (NET) Sambalpur University

(Autonomous College), Rourkela, Odisha, India

\begin{abstract}
The "gap bridgers" and the "gap minders" are the two broad positions, which dominate the debate at present that is significance to the theory of international relations (IR). Nonetheless, absent from this discussion is a wider theoretical in the context, that helps us to step beyond their differences. This article, therefore gives a theoretical account of the relation between politics and information. Scientific knowledge has the political relevance that gets distancing itself in the modern context that happens in a particular politics over the theorizing. In the abstraction, there is political relevance at different stages, which has the relationship in paradoxical that rise in the dimension in three different ways. Politics has the modern concept that has a crucial role for establishing that plays a meta-theory; political space is established by the theories as well as policies have a specific influence on empirical studies. Considering this specific circumstance, also, requires a reassessment of center highlights of the order: its destitution, fracture, and irresponsibility are normal to every advanced science; they work as a driver of logical advancement; and meta-theoretical discussions deal with the political element of advanced sciences. Therefore, IR "s democratic wellspring has significance in its imaginary institutions.
\end{abstract}

KEYWORDS: International Relations Theory\& Modern Politics

Received: Jan 17, 2020; Accepted: Feb 07, 2020; Published: Jun 04, 2020; Paper Id.: IJPSLIRJUN20206

\section{INTRODUCTION}

The case that the control of IR neglects to satisfy its core vocation to create politically pertinent work isn't new (for instance, Wallace 1996). Today, in any case, this case is rehashed and talked about in standard and internet based life (Kristof 2014) and illuminates look into financing arrangements (Bastow, Dunleavy and Tinkler 2014; Desch 2015). The issue of these lines of critical significance for the control and has offered ascend to an energetic discussion. While the objective of creating politically important information is generally shared among IR researchers, the significance of this term and the way to attain the exceptionally challenged. Two expansive positions have emerged.

The "gap bridgers" (Parks and Stern 2014) hold that a lot of IR grant, both standard and basic, is politically insignificant - to a large degree because it focuses on conceptual and meta-theoretical topics of minor concern and makes use of on-screen political characters.

Diplomatic importance is here comprehended as policy relevance and prompts a call for more approach, which is investigation so as to connect the extending gap among speculation and exercise (Avey and Desch 2014; Mearsheimer and Walt 2013; Kurki 2011; Lowenthal et al., 2014). In opposition, the "gap minders" notice to fluctuated types of their communication among legislative issues and the scholarly world that require a more 
extensive origination of political importance. They show that hypothetical work assumes a significant political role in its own privilege and contend that keeping up a separation among political relation and education is a stipulation for diplomatic significance (Eriksson 2014; Bertucci, Borges-Herrero and Fuentes-Julio 2014; Reus-Smit 2012; Zambernardi 2016).

Force as a likelihood to accomplish a particular objective is associated with a societal position - the probability right now is a situation, under which it is conceivable to understand this acting. The force limits of people and gatherings are inconsistent, yet regularly contradicted to one another: they are the devices that are utilized for the execution of various, all the time clashing interests. The intensity of people and gathering accordingly, is a vector consequence of the weight of intensity aspirations from different focuses. So as to conquer disorder that started because of the ceaseless conflict of intensity possibilities in different focuses, there was an organization set up, whose potential permits it to increase a controlling status in these contentions, giving them a structure permitting the aggregation of individuals not exclusively to endure, yet in addition to build up the state.

Its situation concerning the force want of individuals is remarkable to the point that a genuine degree of the force conceivable outcomes of people and gatherings is associated with their situations in the state device. Aside from others, the state is an establishment of sorted out, sovereign, and legitimized brutality on a particular possessed domain. Nonetheless, the state authority can be likewise utilized imaginatively to satisfy social needs. Regardless, the state has to focal a situation in the general public that a challenge for power has most importantly a type of the challenge for power in the state.

As from the political perspective, the state remotely speaks to people, gatherings, and inward foundations; most of political relations right now is a connection of states. The force on the world political system is packed in the states - and it is scattered as needs to be. On the chance, if the existence of several independent power centres only means a temporary anomaly in the internal political system, it signifies to an essential component on the world political framework. As to the universal circle, the political intrigue is above all the state intrigue. Right now talking about the state enthusiasm as an incomplete enthusiasm for the world society isn't extremely precise, in light of the fact that the state intrigue isn't a piece of any wide political intrigue subjected to it and limited by it either from the perspective of setting, or from the perspective of means; as to a solid force capability of express, the state intrigue is accepted better than general or dynamic interests of humanity.

The path to isolating politics and knowledge requires three distinct degrees of reflection, each defining one dimension of politics and science at the same time. Meta-theoretical research aims at educating about common diplomatic concerns. In this way, it gives the concept of modern science origination as the use of all-inclusive inspiration to the idea of things-and of current governmental problems as the interaction of society according to that existence.

Hypotheses, meanwhile, give a record of the connection between marvels like states, classes, people, sexual orientations, firms, standards, societies, assets and along these lines build up specific fields of information that all the while give spaces to political contestation. Experimental examinations, at long last, offer bits of knowledge into specific issues and occasions and thus additionally the way to shape separate strategies. This record recommends that IR grant is politically pertinent at all three degrees of deliberation. It likewise appears, be that as it may, that incomprehensibly, politics and knowledge are most personally linked at the meta-theoretical level which gives the shared belief in their different constitution. From that point on, the difference widens with each progression to solid arrangements. Meta- 
theoretical work, therefore, plays more of a central political role than speculations,and these are also of greater political significance than empirical or strategic inquiries - a result that vindicates and extends the "gap minders" scenario.

This research suggests, in general, that the difference between politics and knowledge is the extension of them within the current context. To ensure the political value of IR grants in this way needs "reflecting the void." Perhaps more importantly, as it may be, it brings to light the fundamental aspects in which IR is, and has continuously been, complicit in ordering politics as of now. Besides, this radically changes the concept of our political responsibilities-which lie to an incredible degree in perceiving, worrying about, and taking responsibility for the political importance of our hypothetical task.

\section{ANALYZING ON POLITICAL RELEVANCE DEBATE}

The political relevance discussion includes a wide array of perspectives and issues. To differentiate between two expansive positions is feasible. The first, the "gap bridgers," typically conceive of political importance as implications for the approach whereas the second, the "gap minders" (Parks and Stern 2014), need a more extensive political origination. Both present possible claims and observational proof. Whatever getting beyond their disagreements needs, there is a conceptual record of political significance itself that is absent from this debate right now.

Many IRs find neglecting to advise sound arrangements (de Felice and Obino 2012; Lepgold and Nincic 2001). In these lines, the "gap-bridgers" claim that IR is constantly neglecting to fulfill the three center requirements for the appropriate job method. Such research will primarily be linked to "exact substances" (Jentleson 2002), "Strong strategic and practical problems" (Sil and Katzenstein 2010), "real political changes" (Kurki 2011), "individuals" rather than "absolute intellectual roles" (Sylvester 2013), "meta-theoretical debates" (Chernoff 2009), or "methodological thoughts and practices" (Mearsheimer and Walt 2013; Avey and Desch 2014). Second, it is regularly thought that strategic importance increases with the existence of the award, with the "consistency" and consistency of our experience (Frieden and Lake 2005), with the accuracy of our speculations (Mearsheimer and Walt 2013). Third, if scholastic inquiries and findings are to be effective techniques, they should be offered to political entertainers in "plain language" (Nye 2008).

\section{THEORIZING THE LIAISON BETWEEN POLITICS AND KNOWLEDGE}

Politics and cognition rely on historical changes. Examining IR"s political significance a modern academic influenceincludes a record of the relationship between theoretical knowledge and politics afterward. Such observations can be identified in all kinds of forms and strategies: in the way of thought of science (Popper 2011; Kuhn 1996; Lakatos and Musgrave 1970), in humanism (Weber 1948; Durkheim 1997), in political economy and history in linguistics, philosophy and political theory just as in IR itself to name just a few.

\section{META-THEORY AND ALSO THE MODERN POLITICS CONSTITUTION}

The key indicator of political meaning in the contemporary debate regarding theory and action is the one most commonly disregarded. It arises from the epistemic-level co-constitutive relation between politics and expertise, which is encapsulated in the theory of meta-theoretical and methodological reflections which current science practices - as well as for IR. Such activities, it gives the usual premise of advanced political and scientific roots. Consequently, meta-theoretical debates are irreplaceable for modern sciences and obstruct a "finish of hypothesis" from now on. Opposition to general assumptions, meta-theoretical discussions are often genuinely concerned and motivated by the advanced sciences" political dimension. 


\section{PRINCIPLE AND THE CONSTITUTION OF POLITICAL SPACES}

The second dimension of political significance comes from the sense, in which the current episteme frameworks, or more specific parts, the field of knowledge itself - triggering the creation of new and continuously evolving fields of research and managing the complex relationships within and between them. Finding IR within this environment shows that the control's "discontinuity," "neediness," and "immaturity" has its fundamental roots in the contemporary episteme itself, and is thus a traditional feature of modern sciences. Within the background of the scientific sciences, it may, those usually deplored features of progressive dynamic hypothesis enhancement. Such theories, create political environments and then become extremely important politically.

The developed regulation of economic ramifications, typically generated during the 19th century by shedding the "moral-philosophical," "political" and "sociological" measures that were an essential part of the political economy (Morgan 2008). Furthermore, the new order of financial implications was motivated by conceptual concerns, by a fixation on ability and the ideal economy that left realistic monetary problems-for example, interest-unanswered and unaddressed (Schabas 2008; Morgan 2008; Banister 2008). In the meantime, the new system of politics was worried about policy-but at the time governments did not regard economic administration as one of their tasks (Schabas 2008). From now on, neither political nor financial aspects were in a position to break down the crucial issues posed at their interface and fizzled in this way, To tackle, for example, the monetary emergency of the 1870s and its political decline (Morgan 2008).This disappointment thus gave the opening to the foundation of humanism - a science that placed "society" as a different circle among political and financial matters (Banister 2008).

\section{STUDIES AND THE IMPACT ON POLITICAL PRACTICE}

The third component of political importance finds characterization in the configuration of located assessments so generally related to the term. There's no question that these inquiries will "bridge the distance" between politics and information at the exact level. Though, that effectively crossing this politics-knowledge isolate forces constrains on arrangement situated investigations. The exact examinations establish a fundamental component of current science, and this logical standing that gives them a more extensive political significance. Surrendering hypothesis and meta-theory for experimental examinations, as generally called for by the "gap-bridgers," their rational argument, and ultimately their political ability, would eventually be undermined.

Accordingly, the monitoring that IR grants require political relevance may have its origins, not only in the inability to perceive the political significance of conceptual and meta-theoretical research but also in the restricted significance of strategically organized investigations themselves-in the way that they would help particular issues and entertainers in general, and henceforth, unlike theories decline to recommend the "excellent methodologies" of states or offer the "large narratives" that border international politics, in particular times.

\section{CONCLUSIONS}

In truth, politics and information are "joined at the hip, and none can thrive without the other, even within their domain" (Nau 2008). Forecasting this connection provokes a more comprehensive understanding of IR"s political significance as well as a re-evaluation of control center qualities. The private linkage between politics and information is formed and duplicated by partitioning in the modern sense. It is only by distinguishing oneself from the peculiarities of politics and establishing the vocabulary of general interpretation that science develops its political relevance. This nonsensical 
relationship flips entirely around the widely held belief that increasing rates of deliberation-from empirical to conceptual and meta-theoretical research-undermine political value. However, with each advancement away from specific approaches, academic work tackles more detailed inquiries tackles larger audiences and assumes a more fundamental position for legislative issues (Eriksson 2014). Every one of these degrees of deliberation, in addition, comprises an essential piece of current science and in this manner additionally of its political significance. "Essentially significant information" is in this directiondelusive without "meta-theoretical reflection" (Reus-Smit 2013) and the other way around.

Finally, the results of this work relate to its findings besides. By reflecting on the usual epistemic principle of modern sciences and modern politics today, the build-up connections between politics and knowledge, and between IR and various controls. It displayed the political importance of unique and strong, fantastic and appalling price, accessible and research-free. Through concentrating on the modern episteme, this work detached fundamentally from the ontological calculation - from the particulars of politics and knowledge, the similarities between IR and other modern sciences, between special and empirical, Simple and ordinary, work of great quality and terrible quality. However, the wellspring of perplexity over the importance of IR has consistently lain in the epistemic assumption of the relation between present-day modern-day politics and sciences.

\section{REFERENCES}

1. Avey, Paul C. and M. C. Desch. (2014) What Do Policymakers Want From Us? Results of a Survey of Current and Former Senior National Security Decision Makers. International Studies Quarterly 58:227-46.

2. ARO, GC, et al. "Assessing the Contribution of The Military Regimes to Political Developments in Post Independent Nigeria, 1966-1999."

3. Bannister, Robert C. (2008) Sociology. In The Cambridge History of Science. Ed. by T. M. Porter and D. Ross. Cambridge: Cambridge University Press, 329-53

4. Bastow, Simon, Patrick Dunleavy and Jane Tinkler. (2014) The Impact of the Social Sciences. How Academics and Their Research Make a Difference. London: Sage.

5. Chernoff, Fred. (2009) Conventionalism as an Adequate Basis for Policy-Relevant IR Theory. European Journal of International Relations 15(1):157-94.

6. de Felice, Damiano and Francesco Obino. (2012) Weaving the Theories and Practice of International Relations. Millennium. Journal of International Studies 40(3):431-7.

7. Durkheim, Emile. (1997) The Division of Labour in Society. Translated by W. D. Halls. New York: Free Press.

8. Eriksson, Johan. (2014) On the Policy Relevance of Grand Theory. International Studies Perspectives 15(1):94-108

9. Frieden, Jeffrey A. and David A. Lake. (2005) International Relations as a Social Science: Rigor and Relevance. Annals of the American Academy of Political and Social Science 600:136-56.

10. Hussain, Ghulam, and AnwaarMohyuddin. "Historical Sketch of Peasant Activism: Tracing Emancipatory Political Strategies of Peasant Activists of Sindh." International Journal Humanities and Social Sciences (Ijhss) 3. 5, Sep 2014, 23-42

11. Jentleson, Bruce W. (2002) The Need for Praxis: Bringing Policy Relevance Back In. International Security 26 (4):169-83.

12. Kristof, Nicholas. (2014) Professors, We Need You! International New York Times, February 15, accessed December 2, 2015,

13. Kuhn, Thomas S. (1996) The Structure of Scientific Revolutions. Chicago: University of Chicago Press.

14. Kurki, Milja. (2011) The Limitations of the Critical Edge. Reflections on Critical and Philosophical IR Scholarship Today. Millennium. Journal of International Studies 40(1):129-46. 
15. Lakatos, Imre and Alan Musgrave, eds. (1970) Criticism and the Growth of Knowledge: Proceedings of the International Colloquium in the Philosophy of Science, London 1965, Vol. 4. Cambridge: Cambridge University Press.

16. Lepgold, Joseph and Miroslav Nincic. (2001) Beyond the Ivory Tower: International Relations Theory and the Issue of Policy Relevance. New York: Columbia University Press.

17. Lowenthal, Abraham F. and Mariano E. Bertucci. (2014) Building Bridges between the Worlds of Thought and Action. In Scholars, Policymakers \& International Affairs, ed. by A. F. Lowenthal and E. Bertucci, 1-14. Baltimore: Johns Hopkins University Press

18. Mannheim, Karl. (1960) Ideology and Utopia. London: Routledge.

19. Mearsheimer John J. and Stephen M. Walt. (2013) Leaving theory behind: Why simplistic hypothesis testing is bad for International Relations. European Journal of International Relations 19(3):427-57

20. Morgan, Mary S. (2008) Economics. In The Cambridge History of Science, ed. by T. M. Porter and D. Ross, 275-305. Cambridge: Cambridge University Press.

21. Nau, Henry R. (2008) Scholarship and Policy-Making: Who Speaks Truth to Whom? In The Oxford Handbook of International Relations, ed. by C. Reus-Smit and D. Snidal, 635-47. Oxford: Oxford University Press. Eriksson, Johan. (2014) On the Policy Relevance of Grand Theory. International Studies Perspectives 15(1):94-108.

22. Nye, Joseph Jr. (2008) International Relations: The Relevance of Theory to Practice. In The Oxford Handbook of International Relations, Ed by C. Reus-Smit and D. Snidal, 648-60. Oxford: Oxford University Press.

23. Parks, Bradley C. and Alena Stern. (2014) In-And-Outers and Moonlighters: An Evaluation of the Impact of Policy-making Exposure on IR Scholarship. International Studies Perspectives 15(1):73-93.

24. Popper, Karl (2011) The Open Society and Its Enemies. London: Routledge.

25. PRASAD, SHIW BALAK. "PRACTICES OF PUBLIC PROTESTS IN MODERN INDIA." International Journal of Political Science, Law and International Relations (IJPSLIR) 9.2, Dec 2019, 63-76

26. Reus-Smit, Christian. (2012) IR Irrelevant? Don't Blame Theory. Millennium. Journal of International Studies 40(3):525-40.

27. Schabas, Margaret. (2008) British Economic Theory from Locke to Marshall. In The Cambridge History of Science, ed. by T. M. Porter and D. Ross, 171-82. Cambridge: Cambridge University Press.

28. Sil, Rudra and Peter J. Katzenstein. (2010) Analytic Eclecticism in the Study of World Politics: Reconfiguring Problems and Mechanisms Across Research Traditions. Perspectives on Politics 8(2):411-31

29. Sylvester, Christine. (2013) Experiencing the end and afterlives of International Relations/theory. European Journal of International Relations 19(3):609-26.

30. Tavassoli, Sina. "Pinter's Political Theatre: A Quest for Socio-Political Spaces of Authority in One for the Road and Party Time." International Journal of English And Literature (IJEL) ISSN (P) (2016): 2249-6912.

31. Wallace, William, (1996) Truth and power, monks and technocrats: theory and practice in international relations. Review of International Studies 22(3):301- 21.

32. Weber, Cynthia. (1994) Good Girls, Little Girls, and Bad Girls: Male Paranoia in Robert Keohane"s Critique of Feminist International Relations. Millennium. Journal of International Studies 23(2):337-49.

33. Zambernardi, Lorenzo. (2016) Politics is too important to be left to political scientists: A critique of the theory-policy nexus in International Relations. European Journal of International Relations 22(1):3-23. 